\title{
Iron Deficiency Stress Influences Physiology of Iron Acquisition in Marigold (Tagetes erecta L.)
}

\author{
Joseph P. Albano ${ }^{1}$ and William B. Miller ${ }^{2}$ \\ Department of Horticulture, Box 340375, Clemson University, Clemson, SC 29634-0375 \\ Additional index words. iron efficiency, plant nutrition, bedding plants, Fe-DTPA, bronze speckle
}

\begin{abstract}
Excised roots of 'First Lady' marigold (Tagetes erecta L.) grown in an aerated 0 Fe nutrient solution had Fe(III)DTPA reductase activity 14-fold greater, and an enhanced ability to acidify the rhizosphere than plants grown in a solution containing $0.018 \mathrm{~mm}(1 \mathrm{ppm})$ Fe-DTPA. Reductase activity and rhizosphere acidification of plants grown in 0.018 and 0.09 mм Fe-DTPA were similar. Manganese concentration in leaves of plants grown in the 0 Fe treatment was 2-fold greater than in leaves of plants grown in the $0.018 \mathrm{~mm}$ Fe-DTPA treatment. These results indicated that 'First Lady' marigold is an Fe-efficient plant that possesses both an inducible or adaptive reductase system and the ability to acidify the rhizosphere, and that these Fe-efficiency reactions do not occur when Fe is sufficient. Chemical name used: ferric diethylenetriaminepentaacetic acid, monosodium salt (Fe-DTPA).
\end{abstract}

Dicots and nongraminaceous monocots only take up ferrous iron (FeII) into the cytoplasm (Marschner, 1995). When Fe is limiting, roots undergo specific physiological and morphological changes that improve Fe uptake. This inducible system for $\mathrm{Fe}$ acquisition is commonly referred to as strategy I Fe-efficiency (Bienfait, 1988; Romheld, 1987). Strategy I is characterized by the inducible reductase system capable of reducing ferric iron to ferrous iron, and is commonly associated with rhizosphere acidification via membrane bound ATPase associated proton extrusion(Bienfait, 1988; Landsberg, 1986; Romheld, 1987; Romheld et al., 1984).

It has been proposed that roots have two novel reductase systems: standard and turbo (Bienfait, 1988). The standard (basic or constitutive) reductase presumably operates under Fe sufficient conditions, and is detected in vitro by ferriccyanide reduction (Bienfait, 1987). The suspected function of the standard reductase system is membrane potential modulation (Bienfait, 1987). The adaptive (turbo) reductase is induced in response to Fe deficiency. The primary function of the adaptive reductase is $\mathrm{Fe}$ acquisition, showing activity against a wide variety of ferric chelates (Bienfait, 1988).

Recent studies, however, do not support the hypothesis of the production of a novel reductase system under Fe deficiency stress, but suggest that the high plasma membrane root reductase activity observed under Fe deficiency stress is an increased expression of both ferricyanide and $\mathrm{Fe}$ (III) chelate reductases (Guerinot and $\mathrm{Yi}$, 1994). Furthermore, studies have found that the inducible reductase can be regulated by, and show activity for, other metal cations (Welch et al., 1993).

Marigolds belong to the order Asterales. Two species of this order have been studied for evidence of Fe-efficiency: Helianthus annuus L. (sunflower) and Lactuca sativa L. (lettuce). Both sunflower and lettuce have an inducible reductase system in response to Fe deficiency, but only sunflower actively acidifies the rhizosphere through proton extrusion (Kramer et al., 1980; Romheld,

Received for publication 28 Apr. 1995. Accepted for publication 26 Sept. 1995 Technical contribution no. 4145. We thank Dennis R. Decoteau, Thomas M. McInnis, Jr., and William C. Bridges, Jr., for consultation in this research. This research was supported in part by The Scotts Co., Fafard Inc., The Fred C. Gloeckner Foundation, and the Clemson Univ. ornamental horticulture competitive grants program. Use of trade names does not imply endorsement of the products named nor criticism of similar ones not named. The cost of publishing this paper was defrayed in part by the payment of page charges. Under postal regulations, this paper therefore must be hereby marked advertisement solely to indicate this fact. ${ }^{1}$ Graduate assistant.

${ }^{2}$ Associate professor.
1987). There have been no published reports characterizing $\mathrm{Fe}$ efficiency reactions in marigold.

Work by Grusak et al. (1990a, b) and Welch and LaRue (1990) demonstrated that Fe toxicity in 'Sparkle' pea (Pisum sativum L.) mutant, E107 (brz brz), is caused by an inability of the plant to control Fe-efficiency reactions. Pea mutant E107, regardless of Fe status in tissue or rhizosphere, physiologically functions as if always under Fe deficiency conditions. This results in continual expression of Fe-efficiency reactions, i.e., enhanced root reductase and ability to cause rhizosphere acidification, which cause the uptake of large amounts of Fe into leaves and Fe toxicity characterized by bronze spotting.

Iron toxicity in 'First Lady' marigold bronze speckle (J.P.A.'s nomenclature) was studied previously (Albano et al., 1996). Bronze speckle is a specific physiological disorder of the leaves associated with high levels of Fe in affected tissue, characterized by chlorotic and bronze necrotic speckling. We sought to determine if $\mathrm{Fe}$ efficiency reactions are a cause of the Fe toxicity disorder bronze speckle as in the Fe toxicity problem of pea E107. The objectives of this study were 1) to determine if marigold is Fe-efficient, possessing both an adaptive reductase and the ability to acidify the rhizosphere in response to Fe deficiency, and 2) to determine physiological responses associated with Fe-efficiency to excess levels of Fe-DTPA in the nutrient solution.

\section{Materials and Methods}

Growing conditions. 'First Lady' marigolds were germinated in Fafard 3B soilless medium (Fafard, Anderson, S.C.) in $56 \times 28$ $\times 6-\mathrm{cm}$ trays in a greenhouse. Fourteen days after sowing, seedlings of uniform growth were removed from the trays, and the roots gently rinsed with tap water. Plants were transferred to a hydroponic system in a controlled environment growth chamber under conditions previously described (Albano et al., 1996). One plant was grown per 2-liter container in nutrient solution adjusted to $\mathrm{pH}$ 5.9 , with $\mathrm{NaOH}$ or $\mathrm{HCl}$. The full strength solution, prepared in distilled, deionized water, contained the following macronutrients (in millimolar concentrations): $2.5, \mathrm{~K}_{2} \mathrm{SO}_{4} ; 2, \mathrm{MgSO}_{4} ; 0.5$, $\mathrm{Ca}\left(\mathrm{H}_{2} \mathrm{PO}_{4}\right)_{2} ; 2, \mathrm{CaNO}_{3} ; 5.14, \mathrm{NH}_{4} \mathrm{NO}_{3} ; 2, \mathrm{NH}_{4} \mathrm{SO}_{4}$ and the following micronutrients (in micromolar concentrations): $0.32, \mathrm{CuSO}_{4}$; $0.76, \mathrm{ZnSO}_{4} ; 46.2, \mathrm{H}_{3} \mathrm{BO}_{3} ; 0.54, \mathrm{MoO}_{3} ; 17.9$, Fe-DPTA; and 9.1, Mn-EDTA (manganese ethylenediaminetetraacetic acid). The concentration of nutrients in the nutrient solution was altered as follows: days 15-17 after sowing, 25\%; days 18-25 after sowing, 
50\%; and days 26-40 after sowing, 100\% (full strength). Treatments were initiated 41 days after seeding. Treatment nutrient solutions were prepared so that final Fe-DTPA concentrations were $0,0.018 \mathrm{~mm}(1 \mathrm{ppm})$, and $0.09 \mathrm{~mm}(5 \mathrm{ppm})$. Treatment solutions were continuously aerated and changed every 7 days at hour ten of the photoperiod.

Rhizosphere acidification. On days 2, 9, and 16 after initiating treatments, a $10 \mathrm{ml}$ sample of the treatment solutions was taken for $\mathrm{pH}$ determination by $\mathrm{pH}$ electrode (Standard Polymer-Body GelFilled Combination Electrode no.13-620-108, Fischer Scientific, Pittsburgh, $\mathrm{Pa}$.). Samples were collected $24 \mathrm{~h}$ after the solution was changed with new treatment solution. Controls consisted of aerated 2-liter containers with treatment solution only (no plants).

Quantification of root reduction of $\mathrm{Fe}(\mathrm{III})$. Root-associated $\mathrm{Fe}(\mathrm{III})$ reduction was quantified by determining $\mathrm{Fe}$ (III) reduction, using a method modified from Landsberg (1986) and Welch et al. (1993). Five freshly cut root tips $(5-8 \mathrm{~mm}$ length, $\approx 6.0 \mathrm{mg}$ fresh weight combined, (day 26) were bathed in $0.2 \mathrm{mM} \mathrm{CaSO}_{4}$ for $5 \mathrm{~min}$ and placed in $4 \mathrm{ml}$ oxygenated assay solution containing $0.2 \mathrm{~mm}$ $\mathrm{CaSO}_{4}, 5 \mathrm{~mm}$ Mes buffer (pH 5.5), $0.1 \mathrm{~mm}$ Fe(III)-DTPA, and 0.3 mM BPDS ( $\mathrm{Na}_{2}$-bathophenanthrolinedisulfonic acid), and $10 \mathrm{~mm}$ sucrose. Sucrose was added to prevent a possible decrease in respiration due to root excision. Assays were conducted in the dark in a water bath at $23 \mathrm{C}$. The absorbance at $535 \mathrm{~nm}$ was determined at 120 min against a blank (minus roots) assay solution. Linearity of the time course of $\mathrm{Fe}$ (III)-reductase activity for the $120 \mathrm{~min}$ incubation period employed for this experiment was established by repeated sampling in several preliminary experiments. Root fresh weight of cut roots were measured at the end of the experiment. The concentration of Fe(II)-BPDS produced was calculated using an extinction coefficient of $22.14 / \mathrm{mm}$ per $\mathrm{cm}$ (Welch et al., 1993).

Mineral determinations. Leaves were harvested on day 30 of treatments. Leaves were consecutively washed $(\approx 10-15 \mathrm{sec}$ each) in a $0.01 \%$ soap solution (Micro; Cole-Parmer, Niles, Ill.), $0.1 \mathrm{~N}$ $\mathrm{HCl}$, and 2 deionized, distilled water rinses. Leaf tissue was ground to pass through a 20 -mesh screen. A half $\mathrm{g}$ of leaf tissue was dry ashed at 500C for $5 \mathrm{~h}$ and prepared for elemental analysis with a modified digestion procedure (Allen et al., 1986). Modifications included 1) after cooling, $15.8 \mathrm{~N} \mathrm{HNO}_{3}$ was added to wet the ash residue, 2 ) wet ash residue was placed on a hot plate at $\approx 80 \mathrm{C}$ until dry, 3) ash was rewetted with $8 \mathrm{ml}$ of $6 \mathrm{~N} \mathrm{HCl}$ and scraped with a plastic spatula, 4) ash solution was quantitatively transferred to a $100 \mathrm{ml}$ volumetric flask and brought to volume with deionized, distilled water, and 5) solution was filtered through filter paper (no.41; Whatman Paper, Maidstone, Kent, U.K.) Tissue was analyzed by atomic absorption spectrophotometry for $\mathrm{Fe}$ and $\mathrm{Mn}$.

Statistics. Data were analyzed to determine the main effects of Fe treatments using an ANOVA. Calculations performed with the general linear model (GLM) procedure of SAS (SAS Inst., Cary, N.C.) Where a significant $\mathrm{F}$ test was observed, means were separated and planned comparisons were made using pairwise $t$ tests. The experiment consisted of three treatments and three replications (single plants) per treatment. Treatments were arranged in a completely randomized design within a controlled environment growth chamber.

\section{Results}

Plant growth characteristics. Plants in the 0 Fe-DTPA treatment began to show signs of interveinal chlorosis on young leaves 7 days after initiating treatment. All plants in the $0.018 \mathrm{~mm}$ and

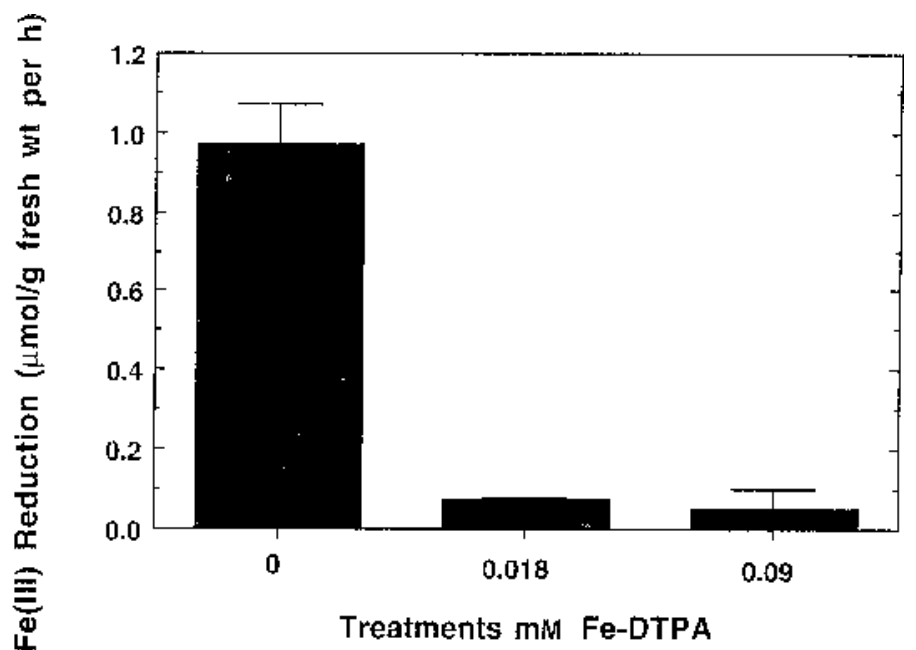

Fig. 1. Ferric reduction of excised roots $(\approx 5-8 \mathrm{~mm}$ sections from root tip) after 26 days growing in 0, $0.018 \mathrm{~mm}$ and $0.09 \mathrm{~mm}$ Fe-DTPA treatments. Bars indicate SE.

$0.09 \mathrm{~mm}$ Fe-DTPA treatments appeared normal for the duration of the experiment.

Quantification of root reduction of $F e(I I I)$. The ferric reduction rate for roots of the 0 Fe-DTPA treatment was 14 and 19 times greater than roots of the $0.018 \mathrm{~mm}$ and $0.09 \mathrm{~mm}$ Fe-DTPA treatments, respectively (Fig. 1). The rates of ferric reduction for roots in the $0.018 \mathrm{~mm}$ and $0.09 \mathrm{~mm}$ Fe-DTPA treatments were not significantly different (Fig. 1).

Acidification of the nutrient solution. Twenty-four hours after initiation of treatments, the $\mathrm{pH}$ of the treatment solutions was similar (pH 5.8-6.0) (Table 1). The pH of the 0 Fe-DTPA treatment on day 9 was reduced $1.8 \mathrm{pH}$ units in a 24-h period from $\mathrm{pH} 5.9$ to 4.1. This was $1 \mathrm{pH}$ unit lower than the $0.018 \mathrm{~mm}$ Fe-DTPA treatment at $\mathrm{pH} 5.1$ (Table 1). On day 16 of treatments, the $\mathrm{pH}$ of the $0 \mathrm{Fe}-\mathrm{DTPA}$ treatment was reduced $1.7 \mathrm{pH}$ units in a $24-\mathrm{h}$ period from $\mathrm{pH} 5.9$ to 4.2 . This was $0.6 \mathrm{pH}$ units lower than the $0.018 \mathrm{~mm}$ Fe-DTPA treatment at $\mathrm{pH} 4.8$ (Table 1). The $\mathrm{pH}$ of both the 0.018 $\mathrm{mm}$ and $0.09 \mathrm{~mm}$ Fe-DTPA treatments decreased over time and were similar (Table 1). The pH of the controls (treatment solution without plants) did not change in the $24-\mathrm{h}$ period following each treatment solution change (data not shown).

Leaf Fe and Mn concentrations. As expected, Fe concentration was more than 4 times lower in leaves of the 0 Fe-DTPA treatment than in the $0.018 \mathrm{~mm}$ and $0.09 \mathrm{~mm}$ Fe-DTPA treatments (Table 2). Manganese concentration in leaves in the 0 Fe-DTPA treatment was 2 times greater than in the $0.018 \mathrm{~mm}$ and $0.09 \mathrm{~mm}$ Fe-DTPA treatments (Table 2).

Table 1. Rhizosphere acidification for a 24-h period following change of treatment solution 0, 0.018, and $0.09 \mathrm{mM} \mathrm{Fe-DTPA}$ on days 1,8 , and 15. All treatments were initially at $\mathrm{pH}$ 5.9.

\begin{tabular}{lllr}
\hline \hline Treatment & \multicolumn{3}{c}{$\mathrm{pH}$} \\
\cline { 2 - 4 } Fe-DTPA $(\mathrm{mM})$ & Day 2 & Day 9 & Day 16 \\
\hline 0 & $5.85 \mathrm{a}^{\mathrm{z}}$ & $4.08 \mathrm{a}$ & $4.18 \mathrm{a}$ \\
0.018 & $6.03 \mathrm{a}$ & $5.06 \mathrm{~b}$ & $4.75 \mathrm{~b}$ \\
0.09 & $5.9 \mathrm{a}$ & $4.86 \mathrm{~b}$ & $4.65 \mathrm{~b}$
\end{tabular}

${ }^{\mathrm{z}}$ Means within a column followed by different letters indicate significant differences between treatments at $P=0.001$, pairwise $t$ test. 
Table 2. Iron and Mn concentrations $\left(\mu \mathrm{g} \cdot \mathrm{g}^{-1}\right)$ in 'First Lady' marigold leaves 30 days after initiating Fe-DTPA treatments.

\begin{tabular}{lcc}
\hline \hline $\begin{array}{l}\text { Treatment } \\
\text { Fe-DTPA }(\mathrm{mM})\end{array}$ & \multicolumn{2}{c}{ Leaf metal concn $\left(\mu \mathrm{g} \cdot \mathrm{g}^{-1}\right)$} \\
\hline \multicolumn{3}{c}{ Fe } \\
0 & \multicolumn{2}{c}{$184 \mathrm{a}^{\mathrm{z}}$} \\
0.018 & $630 \mathrm{~b}$ \\
0.09 & \multicolumn{2}{c}{$787 \mathrm{~b}$} \\
& Mn \\
0 & & $654 \mathrm{a}$ \\
0.018 & & $358 \mathrm{~b}$ \\
0.09 & & $391 \mathrm{~b}$
\end{tabular}

${ }^{\mathrm{z}}$ Means within each metal followed by different letters indicate significant differences between treatments at $P=0.05$, Duncan's multiple range test.

\section{Discussion}

As illustrated in Fig. 1 and in Table 1, 'First Lady' marigold responded to $\mathrm{Fe}$ deficiency with both enhanced root reductase activity and rhizosphere acidification. These responses to $\mathrm{Fe}$ deficiency are expressed by Fe-efficient plants (Romheld, 1987; Bienfait, 1987, 1988). Therefore, this study supports the hypothesis that 'First Lady' marigold is an Fe-efficient plant possessing both an inducible or adaptive reductase system, and the ability to cause rhizosphere acidification via proton extrusion from roots.

The rate of $\mathrm{Fe}(\mathrm{III})$-reduction in 'First Lady' marigold $0 \mathrm{Fe}$ treatment was $0.97 \mu \mathrm{mol} \mathrm{Fe}(\mathrm{II})-\mathrm{BPDS} / \mathrm{g}$ fresh weight per $\mathrm{h}, 14$ times greater than in plants of the $0.018 \mathrm{~mm}$ Fe-DTPA (1 ppm) treatment at $0.07 \mu \mathrm{mol} \mathrm{Fe}(\mathrm{II})-\mathrm{BPDS} / \mathrm{g}$ fresh weight per $\mathrm{h}$. In 'Sparkle' pea, plants grown in $0 \mathrm{Fe}$ nutrient solutions had peak $\mathrm{Fe}(\mathrm{III})$ reductions rates of $0.81 \mu \mathrm{mol} \mathrm{Fe}(\mathrm{II})-\mathrm{BPDS} / \mathrm{g}$ fresh weight per $\mathrm{h}$, a rate 5.4 times greater than in pea grown in Fe sufficient nutrient solutions at $0.15 \mu \mathrm{mol} \mathrm{Fe}(\mathrm{II})$-BPDS/g fresh weight per $\mathrm{h}$ (Welch et al., 1993). In 'Yaglik' pepper (Capsicum annuит L.), plants grown in $0 \mathrm{Fe}$ nutrient solutions had peak $\mathrm{Fe}(\mathrm{III})$ reductions rates of $1.9 \mu \mathrm{mol} \mathrm{Fe(II)-ferrozine/g} \mathrm{fresh} \mathrm{weight} \mathrm{per} \mathrm{h,} \mathrm{a} \mathrm{rate} 26$ times greater than in pepper grown in $\mathrm{Fe}$ sufficient nutrient solutions at $0.08 \mu \mathrm{mol} \mathrm{Fe}(\mathrm{II})-$ ferrozine/g fresh weight per $\mathrm{h}$ (Landsberg, 1986). Even though methodologies differ between our paper and these studies (Landsberg, 1986; Welch et al., 1993), modifications in $\mathrm{Fe}(\mathrm{III})$ reduction rate for 'First Lady' marigold 0 Fe treatment is within the range reported for pea and pepper under Fe deficiency stress.

The $\mathrm{N}$ composition of the nutrient solution used in this study (1 $\mathrm{NH}_{4}^{+}: 1 \mathrm{NO}_{3}^{-}$) is not typical for studying rhizosphere acidification under $\mathrm{Fe}$ deficiency conditions because $\mathrm{NH}_{4}^{+}$uptake into roots is cationically balanced by proton extrusion into the rhizosphere, causing acidification of the root zone (Marschner, 1995). The nutrient solution $\mathrm{N}$ formulation used in this study was chosen to simulate the $\mathrm{N}$ formulation of many of the commercially produced 20-10-20 soluble fertilizers used in the nursery and greenhouse industries, typically containing up to $40 \%$ of $\mathrm{N}^{2} \mathrm{NH}_{4}^{+}$. In this study, plants grown in the $0 \mathrm{Fe}$ treatment acidified the rhizosphere (nutrient solution) more than plants grown in the Fe sufficient treatments ( 0.018 and $0.09 \mathrm{~mm}$ Fe-DTPA). These findings support the work of Alloush et al. (1990) on the Fe deficiency response of ILC 195 chickpea (Cicer arietinum L.) to $\mathrm{N}$ form. Alloush et al. (1990) reported that chickpea plants grown in a minus $\mathrm{Fe}, \mathrm{NH}_{4}^{+}-$ $\mathrm{N}$ nutrient solution caused greater rhizosphere acidification than plants grown in a $\mathrm{Fe}$ sufficient $\mathrm{NH}_{4}{ }^{+}-\mathrm{N}$ nutrient solution. The rhizosphere acidification response of chickpea grown in minus $\mathrm{Fe}$, $\mathrm{NH}_{4}^{+}-\mathrm{N}$ nutrient solutions was consistent with that of plants grown in minus $\mathrm{Fe}, \mathrm{NO}_{3}^{-}-\mathrm{N}$ nutrient solutions though acidification was enhanced by $\mathrm{NH}_{4}^{+}{ }^{+} \mathrm{N}$ (Alloush et al., 1990).

The reductase induced under Fe deficiency has been shown to have the ability to reduce other metal cations. For example, $\mathrm{Mn}$ (Marschner et al., 1982), Zn (Jolley and Brown, 1991), and $\mathrm{Cu}$ (Welch et al., 1993). In the absence of Fe, 'First Lady' marigolds showed a greater increase in Mn concentration in leaves as compared to the Fe containing treatments (Table 2). This corroborates with earlier studies where the leaves of 'First Lady' marigold grown hydroponically in a $0 \mathrm{Fe}$ nutrient solution had 3.7 times greater Mn concentration than in leaves of plants grown in a nutrient solution containing $0.018 \mathrm{~mm}$ Fe-DTPA (Albano et al., In press). The increase in leaf $\mathrm{Mn}$ in response to Fe deficiency may, in part, be due to the ability of the induced reductase to reduce Mn. The ability of the induced reductase to reduce Mn was not directly determined in this study, but should be investigated in the future.

Previous studies in hydroponics (Albano et al., 1996) have shown that Fe-DTPA treatments greater than $0.18 \mathrm{~mm}$ Fe-DTPA cause bronze speckle, a Fe toxicity disorder characterized by a speckled pattern of leaf chlorosis, bronze necrosis, and downward leaf curling. Other studies with 'Sparkle' pea mutant, E107 (brz $b r z$ ) have linked an inability to control Fe-efficiency reactions with Fe toxicity (Grusak et al., 1990a; Grusak et al., 1990b; Welch and LaRue, 1990) Therefore, the second objective of this study was to determine if physiology associated with $\mathrm{Fe}$ acquisition under $\mathrm{Fe}$ deficiency conditions for 'First Lady' marigold functions when $\mathrm{Fe}$ is sufficient. This would rule out the possibility that Fe-efficiency reactions are a cause of the Fe toxicity disorder bronze speckle in 'First Lady' marigold.

The reductase system operating under Fe sufficient conditions has little activity on synthetic ferric chelates (Bienfait, 1987, 1988). Our work supports this finding, as very little BPDS oxidation i.e., Fe(III)-DTPA reduction, was observed in roots of plants grown in $0.018 \mathrm{~mm}$ or $0.09 \mathrm{~mm}$ Fe-DTPA treatments (Fig. 1). Further, the $0.018 \mathrm{~mm}$ and $0.09 \mathrm{~mm}$ Fe-DTPA treatments did not differ in proton extrusion, and had a $\mathrm{pH}$ higher than the $0 \mathrm{Fe}$ treatment (Table 1). Based on these observations, we conclude that the physiological responses associated with Fe-efficiency, i.e., enhanced root reductase and ability to cause rhizosphere acidification, are not normally expressed in 'First Lady' marigolds when supplied with soluble Fe, such as Fe-DTPA. This indicates that the high $\mathrm{Fe}$ uptake into marigold leaves leading to bronze speckle is not caused by an inability of the plant to control Fe-efficiency reactions, as in 'Sparkle' pea mutant, E107 ( $b r z b r z)$. Even though our current findings do not directly link Fe-efficiency reactions to bronze speckle, the possibility exists that cultural practices in the commercial setting such as fertilizer program, may influence Feefficiency reactions; indirectly contributing to the development of the disorder.

\section{Literature Cited}

Albano, J.P., W.B. Miller, and M.C. Halbrooks. 1996. Iron toxicity stress causes bronze speckle, a specific physiological disorder of marigold (Tagetes erecta L.). J. Amer. Soc. Hort. Sci. 121:430-437.

Allen, S.E., H.M. Grimshaw, and A.P. Rowland. 1986. Chemical analysis, p. 301. In: P.D. Moore and S.B. Chapman (eds.). Methods in plant ecology. 2nd ed. Blackwell Sci. Publ., Oxford.

Alloush, G.A., J. Le Bot, F.E. Sanders, and E.A. Kirby. 1990. Mineral nutrition of chickpea plants supplied with $\mathrm{NO}_{3}$ or $\mathrm{NH}_{4}-\mathrm{N}$. I. Ionic balance in relation to iron stress. J. Plant Nutr. 13:1575-1590.

Bienfait, F. 1987. Biochemical basis of iron efficiency reactions in plants, p. 339-349. In: G. Winkelmann, D. van der Helm, and J.B. Neilands 
(eds.). Iron transport in microbes, plants, and animals. VCH, Weinheim, Germany.

Bienfait, H.F. 1988. Mechanisms in Fe-efficiency reactions of higher plants. J. Plant Nutr. 11:605-629.

Grusak, M.A., R.M. Welch, and L.V. Kochain. 1990a. Physiological characterization of a single-gene mutant of Pisum sativum exhibiting excess iron accumulation. Plant Physiol. 93:976-981.

Grusak, M.A., R.M. Welch, and L.V. Kochain. 1990b. Does iron deficiency in Pisum sativum enhance the activity of the root plasmalemma iron transport protein? Plant Physiol. 94:1353-1357.

Guerinot, M. and Y. Yi. 1994. Iron: Nutritious, noxious, and not readily available. Plant Physiol. 104:815-820.

Jolley, V.D. and J.C. Brown. 1991. Factors in iron-stress response mechanism enhanced by Zn-deficiency in Sanilac, but not Saginaw navy bean. J. Plant. Nutr. 14:257-265.

Kramer, D., V. Romheld, E. Landsberg, and H. Marschner. 1980. Induction of transfer-cell formation by iron deficiency in the root epidermis of Helianthus annus L. Planta 147:335-339.

Landsberg, E. 1986. Function of rhizodermal transfer cells in the Fe stress response mechanism of Capsicum annum L. Plant Physiol. 82:511-517.
Marschner, H. 1995. Mineral nutrition of higher plants. 2nd ed. Academic Press, London.

Marschner, H., V. Romheld and H. Ossenberg-Neuhaus. 1982. Rapid method for measuring changes in $\mathrm{pH}$ and reducing processes along roots of intact plants. Z. Pflanzenphysiology 105:407-416.

Romheld, V. 1987. Existence of two different strategies for the acquisition of iron in higher plants, p. 353-374. In: G. Winkelmann, D. van der Helm, and J.B. Neilands (eds.). Iron transport in microbes, plants, and animals. VCH, Weinheim, Germany.

Romheld, V., C. Müller, and H. Marschner. 1984. Localization and capacity of proton pumps in roots of intact sunflower plants. Plant Physiol. 76:603-606.

Welch, R.M. and T.A. La Rue. 1990. Physiological characteristics of Fe accumulation in the 'Bronze' mutant of Pisum sativum L., cv 'Sparkle' E107 (brz brz). Plant Physiol. 93:723-729.

Welch, R.M., W.A. Norvell, S.C. Schaefer, J.E. Shaff, and L.V. Kochian. 1993. Induction of iron(III) and copper(II) reduction in pea (Pisum sativum $\mathrm{L}$.) roots by $\mathrm{Fe}$ and $\mathrm{Cu}$ status: Does the root-cell plasmalemma $\mathrm{Fe}(\mathrm{III})$-chelate reductase perform a general role in regulating cation uptake? Planta 190:555-561. 